\title{
Pengaruh Jejaring Sosial Facebook Terhadap Prestasi Belajar Mahasiswa Teknik Informatika Di Universitas
}

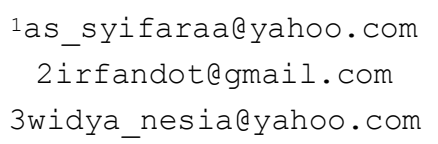

Intan Mutia*1, Puput Irfansyah $^{* 2}$, Luh Putu Widya Adnyani*3

*Fakultas Teknik dan MIPA, Universitas Indraprasta PGRI Jakarta

Jl. Nangka No.58 C Tanjung Barat, Jagakarsa, Jakarta Selatan

\begin{abstract}
Abstrak - Proses pembelajaran hendaknya tidak hanya untuk pencapaian target materi tetapi juga pada pemahaman materi tersebut. Upaya peningkatan prestasi belajar peserta didik tidak terlepas dari berbagai faktor yang mempengaruhinya. Prestasi menurut TulusTu'u merupakan hasil yang dicapai seseorang ketika mengerjakan tugas atau kegiatan tertentu. Prestasi akademik merupakan hasil yang diperoleh dari kegiatan pembelajaran di sekolah yang bersifat kognitif dan biasanya ditentukan melalui pengukuran dan penilaian. Di bantu dengan penggunaan internet dapat meningkatkan minat belajar peserta didik sehingga tujuan pembelajaran terpenuhi. Berbagai macam konten tersedia di internet, mulai dari materi-materi pembelajaran, bisnis, gambar-gambar, audio dan video, hingga jejaring sosial. Dalam kaitan dengan pembelajaran, media Facebook diharapkan mampu membekali peserta didik keterampilan yang dapat menjawab permasalahan mendatang Penelitian ini akan menghasilkan sebuah kajian pengaruh Facebook yang dapat diakses baik dalam keadaan online untuk menunjang pembelajaran. Penelitian ini adalah penelitian kuantitatif dengan metode regresi linier untuk melihat pengaruh dan uji korelasi untuk melihat keterkaitan antara dua variabel yang ada yaitu penggunaan Facebook dan prestasi belajar mahasiswa. Responden dari penelitian ini adalah 300 mahasiswa dari beberapa universitas yang ada di Jakarta Selatan Terdapat korelasi antara jejaring social facebook dengan prestasi belajar mahasiswa. Terdapat pengaruh yang signifikan jejaring social facebook terhadap prestasi belajar mahasiswa. Hal ini terlihat dari hasil uji regresi linier sederhana yang ditunjukkan dengan nilai sig.0,00 < $\mathbf{0 , 0 5}$.
\end{abstract}

Kata kunci-Pengaruh, Prestasi, Belajar, jejaring social, Facebook

\section{PENDAhUluan}

Pendidikan dalam penyelenggaraannya di sekolah melibatkan guru atau dosen sebagai pendidik dan siswa atau mahasiswa sebagai peserta didik, melalui adanya interaksi belajar mengajar atau proses pembelajaran. Dalam pembelajaran, pendidik harus memahami hakikat materi pelajaran yang diajarkannya dan memahami berbagai model pembelajaran yang dapat merangsang kemampuan peserta didik untuk belajar. Proses pembelajaran hendaknya tidak hanya untuk pencapaian target materi tetapi juga pada pemahaman materi tersebut. Upaya peningkatan prestasi belajar peserta didik tidak terlepas dari berbagai faktor yang mempengaruhinya. Pengertian prestasi menurut TulusTu'u [1] merupakan hasil yang dicapai seseorang ketika mengerjakan tugas atau kegiatan tertentu. Prestasi akademik merupakan hasil yang diperoleh dari kegiatan pembelajaran di sekolah yang bersifat kognitif dan biasanya ditentukan melalui pengukuran dan penilaian, sedangkan menurut Slameto [2] bahwa belajar adalah suatu proses usaha yang dilakukan seseorang untuk memperoleh suatu perubahan tingkah laku yang baru secara keseluruhan, sebagai hasil pengalamannya sendiri dalam interaksi dengan lingkungannya. Kita tentu sudah tidak aneh lagi mendengar ataupun menggunakan situs jejaring social Facebook. Facebook merupakan situs jejaring sosial yang paling populer di dunia untuk saat ini, mengingat situs ini kaya akan fitur yang dimilikinya dan penggunaannya pun sangat sederhana. Dalam kaitan dengan pembelajaran, media Facebook diharapkan mampu membekali peserta didik keterampilan yang dapat menjawab permasalahan mendatang.Penggunaan jejaring social Facebook bukan hanya berdampak positif bagi penggunanya tetapi juga dapat berdampa knegatif. Peserta didik diharapkan dapat mengembangkan diri terhadap kemajuan zaman kearah yang positif dengan pemikiran yang kritis, sistematis, logis, kreatif yang dibarengi dengan kemauan serta kerjasama di berbagai bidang, sebab Facebook memiliki fitur-fitur pendukung yang memungkinkan peserta didik dapat belajar dengan kondisi belajar yang berdaya tarik dan menyenangkan. Pengaruh Facebook terutama bagi mahasiswa Teknik Informatika sangat besar, selain sebagai media sosial juga sebagai sarana mahasiswa berbagi pengetahuan dan bahan ajar. Hal ini menjadikan proses pembelajaran yang telah ada selama ini menjadi lebih mudah dan hasil atau taraf kemampuan 
mahasiswa meningkat sehingga mahasiswa lebih bersemangat, bergairah dan tertarik dalam pembelajaran

\section{LANDASAN TEORI}

\section{A. Facebook}

Media Sosial merupakan salah satu media internet yang hampir semua kalangan menggunakannya. "Social network sites (SNSs), such as Facebook, are one of the fastest-growing types of websites on the Internet", yang diartikan bahwa sosial media seperti Facebook adalah salah satu media sosial tercepat pertumbuhannya dalam Internet [3] Facebook diluncurkan pertama kali pada tanggal 4 Februari 2006 oleh seorang mahasiswa Harvard University, Mark Zuckerberg. Nama Facebook sendiri diinspirasi oleh Zuckerberg dari sebuah istilah di kalangan kampus seantero AS untuk saling mengenal antar sesama civitas akademiknya. Awalnya para penggunanya hanya dikhususkan bagi para mahasiswa di kampus Harvard University. Lalu kemudian diperluas ke sejumlah kampus di wilayah Boston (Boston College, Boston University, Northeastern University, Tufts University) dan kampus-kampus lainnya seperti Rochester, Stanford, NYU, Northwestern, and Ivy League. Menyusul kemudian sejumlah kampus lain di AS. Akhirnya, penggunanya lebih diperluas lagi ke sejumlah kampus lain di seluruh dunia. Tanggal 11 September 2006, Facebook membuat satu langkah penting dengan mengizinkan aksesnya ke seluruh netter yang mempunyai alamat email valid, namun, dengan pembatasan usia. Pengguna dapat memilih untuk bergabung dengan satu atau lebih jaringan yang tersedia, seperti berdasarkan sekolah tingkat atas, tempat kerja, atau wilayah geografis. Pembelajaran berbasis e-learning, salah satu pemanfaatannya melalui jejaring sosial Facebook telah banyak dilakukan. Menurut Permana [4] Dengan menggunakan konsep elearning sebagai infrastruktur pembelajaran berbasis content, dimungkinkan materi yang disajikan dapat disesuaikan (flexibelity) dengan kebutuhan pengguna, sedangkan Hambali [5] mengemukakan istilah e-learning sama dengan komunikasi dalam suatu lingkungan, dimana komunikasi merupakan salah satu hal paling penting. Dengan perkembangan teknologi informasi yang semakin pesat, komunikasi dapat dilakukan berbagai berbagai cara, salah satunya yang sekarang berkembang adalah melalui situs jejaring sosial Facebook.

\section{B. Prestasi Belajar}

Prestasi Belajar Poerwanto [6] memberikan pengertian prestasi belajar yaitu " hasil yang dicapai oleh seseorang dalam usaha belajar sebagaimana yang dinyatakan dalam raport" Berdasarkan pengertian diatas, maka dapat dijelaskan bahwa prestasi belajar merupakan tingkat kemanusiaan yang dimiliki siswa dalam menerima, menolak dan menilai informasi-informasi yang diperoleh dalam proses belajar mengajar. Belajar merupakan aktifitas kehidupan yang dilakukan oleh seorang manusia sehari-hari. Slameto dalam Psikologi Belajar [2] menjabarkan bahwa belajar adalah suatu proses usaha yang dilakukan individu untuk memperoleh suatu perubahan tingkah laku yang baru secara keseluruhan, sebagai hasil pengalaman individu itu sendiri dalam interaksi dengan lingkungannya.

\section{Pengertian Prestasi}

Menurut Djamarah [7] "Prestasi adalah hasil dari suatu kegiatan yang telah dikerjakan, diciptakan baik secara individu maupun secara kelompok". Sedangkan menurut Mas'ud Hasan Abdul Dahar dalam Djamarah [7] bahwa "prestasi adalah apa yang telah dapat diciptakan, hasil pekerjaan, hasil yang menyenangkan hati yang diperoleh dengan jalan keuletan kerja”.

Penelitian relevan yang terkait dengan penelitian ini dilihat berdasarkan dari hasil penelitian yang telah dicapai, yaitu penelitian Moh. Khoirun Ni'am, Rudy Kustijono [8] "Pengembangan Pembelajaran Smp Melalui Facebook Pada Materi Alat Optik". Pembelajaran melalui media facebook yang ditinjau dari validitasnya dapat digunakan sebagai media pembelajaran dengan cara memanfaatkan fitur-fitur yang ada didalam facebook sebagai sarana belajar mengajar. Berdasarkan validasi yang telah dilakukan oleh ahli media / dosen, guru mata pelajaran diperoleh bahwa pembelajaran melalui media facebook yang ditinjau dari kepraktisan dan efektifitasnya layak digunakan sebagai media dalam pembelajaran. Hal ini dibuktikan dengan hasil validasi kelayakan media dari ahli media / dosen dan guru mata pelajaran fisika yang mengatakan bahwa media tersebut sangat membantu untuk proses belajar mengajar, dari kepraktisannya maupun efektifitasnya. Setelah diuji cobakan kepada siswa, diperoleh hasil belajar siswa yang meningkat dari sebelum menggunakan media facebook dan setelah menggunakan media facebook.

Penelitian yang dilakukan oleh Evi Nuryani [9] "Hubungan Intensitas Mengakses Facebook dengan Motivasi Belajar siswa SMA Negeri 2 Tenggarong Seberang." Hasil penelitian menyimpulkan bahwa rendahnya intensitas mengakses Facebook siswa diikuti dengan tingginya motivasi dalam belajar. Dan sebaliknya semakin sering siswa mengakses Facebook maka semakin rendah pula motivasi belajar yang mereka miliki. Ada beberapa faktor yang menyebabkan hal ini dapat terjadi yakni siswa yang jarang mengakses Facebook mereka akan banyak meluangkan waktu mereka untuk belajar, dan waktu belajar mereka tidak terganggu dengan kegiatankegitan yang membuat waktu belajar mereka tepangkas, sehingga motivasi dalam belajar yang mereka miliki meningkat dan akhirnya prestasi dan nilai-nilai merekapun bagus.

Penelitian yang dilakukan oleh Evin Yudhi Setyono [8] "Pengaruh Penggunaan Media Jejaring Sosial Edmodo Terhadap Hasil Belajar Mahasiswa Pada Topik Pembuatan Kurva-S Menggunakan Microsoft Excell." Hasil penelitian menyatakan Melalui media pembelajaran online Edmodo dirasa mampu menciptakan pembelajaran E-learning sehingga aktivitas dan interaksi belajar mahasiswa tetap terjaga sekalipun tidak ada jadwal pertemuan/tatap muka di kelas. Pemaparan materi dan proses diskusi yang terjadi mampu membantu proses belajar mahasiswa dalam membuat kurva-S menggunakan Microsoft Excell. Penilaian yang transparan di Edmodo diduga juga mampu menarik minat belajar 
mahasiswa, karena mahasiswa merasa pekerjaannya dihargai secara objektif.

\section{METODE PENELITIAN}

Penelitian ini adalah penelitian kuantitatif dengan metode regresi linier untuk melihat pengaruh dan uji korelasi untuk melihat keterkaitan antara dua variabel yang ada yaitu penggunaan Facebook dan prestasi belajar mahasiswa. Responden dari penelitian ini adalah 300 mahasiswa dari Universitas Swasta yang ada di Jakarta Selatan. Jumlah Universitas dan mahasiswa yang dijadikan sampel dari penelitian ini diambil dengan teknik pengumpulan data secara bertahap (multistage sampling).

\section{HASIL DAN PEMBAHASAN}

Hasil perhitungan deskriptif masing-masing variabel secara lengkap dapat dilihat pada lampiran. Uraian singkat hasil perhitungan statistik deskriptif tersebut akan dikemukakan dalam tabel berikut ini:

TABEL I

DESKRIPSI DATA PENELITIAN

\begin{tabular}{|l|r|r|}
\hline & $\begin{array}{r}\text { Jejaring Sosial } \\
\text { FB }\end{array}$ & Prestasi IMK \\
\hline N Valid & 35 & 35 \\
Mean & 0 & 0 \\
Median & 53.6857 & 77.8857 \\
Mode & 54.0000 & 77.0000 \\
Std. Deviation & 59.00 & $77.00^{\mathrm{a}}$ \\
Variance & 5.77913 & 9.88692 \\
Skewness & 33.398 & 97.751 \\
Std. Error of & -.127 & .463 \\
Skewness & .398 & .398 \\
Kurtosis & 1.494 & -.148 \\
Std. Error of & .778 & .778 \\
Kurtosis & 38.00 & 60.00 \\
Minimum & 67.00 & 97.00 \\
Maximum & 1879.00 & 2726.00 \\
Sum &
\end{tabular}

a. Multiple modes exist. The smallest value is shown

\section{A. Data Jejaring Sosial Facebook $(X)$}

Data dari pengaksesan jejaring social facebook diperoleh berdasarkan data angket obyektif berbentuk pernyataan yang diberikan kepada mahasiswa sebanyak 20 pernyataan.

Berdasarkan Tabel. I di atas didapatkan bahwa skor maksimum 67 sementara skor minimum 38. Tingkat pengaksesan facebook mahasiswa berada pada angka rata-rata 53,67; standar deviasi 5,78; dan median 54. Angka standar deviasi 5,78 atau sama dengan $10,77 \%$ dari skor rata-rata. Ini menunjukan bahwa variasi yang mengakses facebook relatif cukup. Maka dapat disimpulkan bahwa data pengaksesan jejaring sosial facebook representatif. Lebih jelasnya disajikan dalam bentuk grafik histogram pada gambar 4.1 dan 4.2:

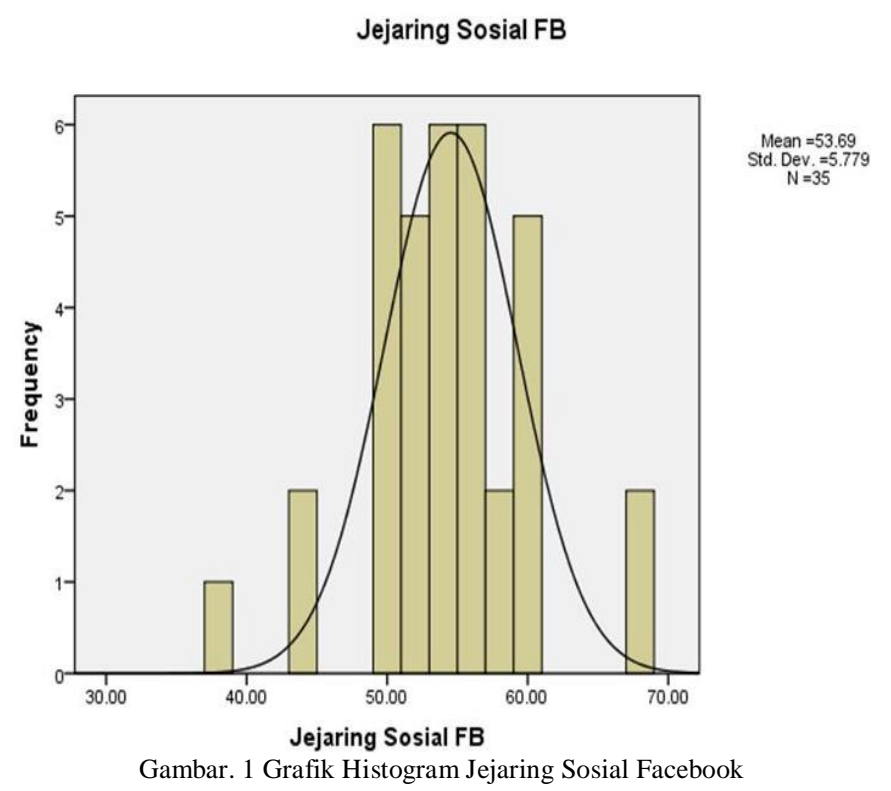

Berdasarkan grafik di atas dapat disimpulkan bahwa tingkat sebaran data akses jejaring social facebook relatif normal karena sebarannya banyak berada dalam kurva normal. Sedangkan data yang berada di luar kurva normal relatif sedikit.

\section{B. Data Prestasi Belajar IMK Mahasiswa (Y)}

Data dari prestasi belajar IMK mahasiswa diperoleh berdasarkan hasil tes obyektif berbentuk pilihan ganda (multiple choice test). Butir soal terdiri dari 20 item dengan 35 orang responden, dimana mahasiswa diharuskan menjawab soal IMK yang telah dipelajari, berdasarkan soal yang sudah dirancang. Tiap itemnya diberi skor 1 untuk jawaban benar dan 0 untuk jawaban salah, kemudian ditranformasikan dalam bentuk nilai.

Berdasarkan Tabel. I di atas didapatkan bahwa nilai maksimum 97 sementara nilai minimumnya 60. Tingkat prestasi belajar IMK mahasiswa berada pada angka rata-rata 77,89; standar deviasi 9,89; dan median 77. Angka standar deviasi 9,89 atau sama dengan $12,70 \%$. Dari nilai rata-rata ini menunjukan bahwa variasi prestasi belajar IMK mahasiswa relatif cukup. Maka dapat disimpulkan bahwa data prestasi belajar IMK mahasiswa repersentatif.

Berikut disajikan grafik histogram yang memberikan gambaran lebih lanjut mengenai distribusi skor prestasi belajar IMK. 


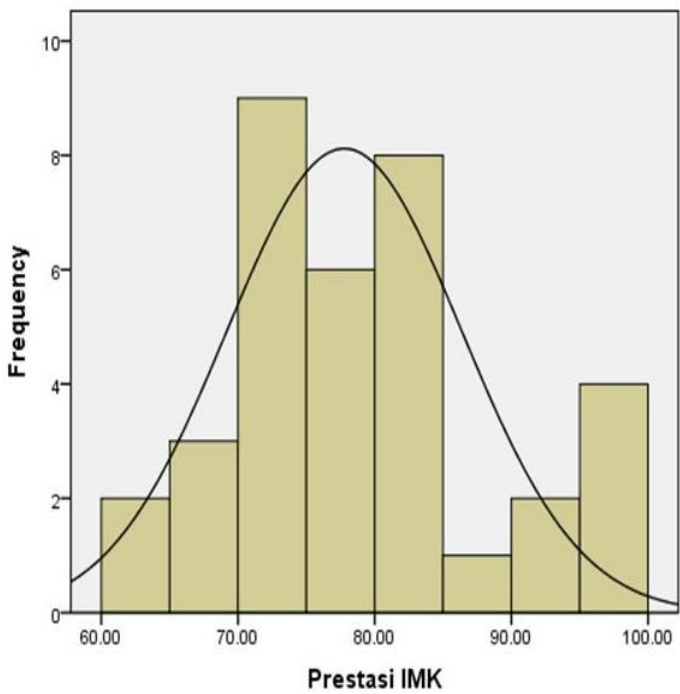

Gambar. 2

Grafik Histogram Prestasi belajar IMK Mahasiswa

Berdasarkan grafik di atas dapat disimpulkan bahwa tingkat sebaran data prestasi belajar IMK relatif normal karena sebarannya banyak berada (secara mayoritas) dalam kurva normal. Sedangkan data yang berada di luar kurva normal relatif kecil.

Data variabel penelitian yang dianalisis dengan menggunakan analisis statistik inferensial melalui teknik korelasi dan regresi linier sederhana harus memenuhi beberapa persyaratan. Di antara persyaratan tersebut adalah:

1.Data bersumber dari sampel berupa pasangan data variabel $\mathrm{X}$ dan variabel $\mathrm{Y}$ harus diambil secara acak dan memenuhi sampel minimum.

2.Untuk setiap kelompok harga variabel $\mathrm{X}$, dan variabel $\mathrm{Y}$ harus independen dan berdistribusi normal.

Hubungan pasangan data variabel $\mathrm{X}$, dan variabel $\mathrm{Y}$ harus linier.

\section{Uji Normalitas}

Pengujian normalitas dilakukan terhadap data variabel Y dan $\mathrm{X}$, dengan rumusan hipotesis statistik dibawah ini:

$\mathrm{H}_{0}=$ data sampel berdistribusi normal

$\mathrm{H}_{1}=$ data sampel tidak berdistribusi normal

Perhitungan dilakukan dengan bantuan komputer melalui program aplikasi SPSS version 16.0 for Windows. Menurut ketentuan yang ada pada program tersebut, maka kriteria dari normalitas data adalah "jika $p$ value $\left(\right.$ Sig) $>0.05$ maka $\mathrm{H}_{0}$ diterima dan sebaliknya $\mathrm{H}_{1}$ ditolak, yang berarti data pada sampel tersebut berdistribusi normal. Nilai pvalue (Sig) adalah bilangan yang tertera pada kolom Sig dalam tabel hasil atau output perhitungan pengujian normalitas oleh program SPSS tersebut. Dalam hal ini digunakan metode KolmogorovSmirnov. Hasil perhitungan normalitas data dapat dilihat pada tabel di bawah ini:
TABEL II

REKAPITUlasi Hasil PENGUJian NORMALITAS

One-Sample Kolmogorov-Smirnov Test

\begin{tabular}{|ll|r|r|}
\hline & & Jejaring Sosial FB & Prestasi IMK \\
\hline N & & 35 & 35 \\
Normal Parameters & Mean & 53.6857 & 77.8857 \\
& Std. Deviation & 5.77913 & 9.88692 \\
Most Extreme Differences & Absolute & .123 & .158 \\
& Positive & .122 & .158 \\
& Negative & -.123 & -.088 \\
Kolmogorov-Smimov $Z$ & & .728 & .936 \\
Asymp. Sig. (2-tailed) & & .665 & .345 \\
\hline
\end{tabular}

a. Test distribution is Normal.

Berdasarkan Tabel II Uji normalitas menggunakan metode Kolmogorov-Smirnov pada variabel Jejaring Sosial (X) diperoleh angka Asymp. Sig. (2-tailed) sebesar 0,665 lebih besar dari 0,05. Variabel Prestasi IMK Mahasiswa (Y) diperoleh angka Asymp. Sig. (2-tailed) sebesar 0,345 lebih besar dari 0,05. Dari data yang diperoleh nilai $p$ value lebih besar dari 0,05 maka $\mathrm{H}_{1}$ ditolak, sehingga dapat disimpulkan bahwa data variabel Jejaring Sosial (X) dan Variabel Prestasi IMK Mahasiswa (Y) berdistribusi normal.

\section{Pengujian Linieritas Garis Regresi}

Perhitungan dilakukan dengan bantuan komputer melalui program SPSS version 16.0 for Windows, dengan ketentuan yang ada pada program tersebut. Kriteria dari normalitas data adalah "jika $\mathrm{Sig}>0.05$, maka $\mathrm{H}_{0}$ diterima dan sebaliknya $\mathrm{H}_{1}$ ditolak. Ini berarti bahwa garis regresi tersebut bersifat linier. Nilai Sig adalah bilangan yang tertera pada kolom Sig baris Deviation from Linearity dalam tabel ANOVA hasil perhitungan pengujian linieritas garis regresi oleh program SPSS version 16.0 for Windows.

Linieritas Garis Regresi Pengaruh Variabel jejaring social facebook $\left(X_{1}\right)$ terhadap Variabel Prestasi Belajar IMK $(Y)$.

Hasil perhitungan pengujian linieritas garis regresi hubungan antara variabel bebas jejaring social facebook terhadap variabel terikat prestasi belajar IMK mahasiswa dapat dilihat pada tabel di bawah ini: 
TABEL III

Hasil Pengujian Linieritas Garis Regresi Pengaruh JEJARING SOSIAL FACEBOOK $\left(\mathrm{X}_{1}\right)$ TERHADAP PRESTASI BELAJAR IMK $(\mathrm{Y})$

\begin{tabular}{|c|c|c|c|c|c|c|c|}
\hline \multicolumn{8}{|c|}{ ANOVA Table } \\
\hline & & & $\begin{array}{l}\text { Sum of } \\
\text { Squares }\end{array}$ & $d f$ & $\begin{array}{l}\text { Mean } \\
\text { Square }\end{array}$ & $\mathrm{F}$ & Sig. \\
\hline \multirow{6}{*}{$\begin{array}{l}\text { Prestasi IMK* } \\
\text { Jejaring Sosial FB }\end{array}$} & Between & (Combined) & 2131.160 & 13 & 163.935 & 2.887 & .015 \\
\hline & Groups & Linearity & 1683.757 & 1 & 1683.757 & 29.654 & .000 \\
\hline & & Deviation from & 4700 & & 3709 & 657 & 772 \\
\hline & & Linearity & & & & & \\
\hline & \multicolumn{2}{|c|}{ Within Groups } & 1192.383 & 21 & 56.780 & & \\
\hline & \multicolumn{2}{|l|}{ Total } & 3323.543 & 34 & & & \\
\hline
\end{tabular}

Dari Tabel III di atas terlihat bahwa nilai pada kolom Sig baris Deviation from Linearity adalah 0.772 lebih besar dari 0.05, sehingga $\mathrm{H}_{1}$ ditolak, maka dapat disimpulkan variabel jejaring social facebook (X) terhadap variabel prestasi belajar IMK mahasiswa (Y) tersebut bersifat linier.

Langkah berikutnya adalah melakukan uji hipotesis terhadap variable yang ada. Berdasar hasil SPSS diperoleh table 4.4, 4.5 dan 4.6:

TABEL IV

UJi KoEF. REgResi Determinasi VARIABEl JEJARING SoSIAL FACEBOOK (X) TERHADAP VARIABEL PRESTASI BELAJAR IMK $(\mathrm{Y}))$

\begin{tabular}{|c|c|c|c|c|c|c|c|c|c|}
\hline \multirow[b]{3}{*}{ Mod } & \multicolumn{9}{|c|}{ Model Summary ${ }^{0}$} \\
\hline & & & & Std Error & & Char & ge Statis & & \\
\hline & $R$ & $\begin{array}{c}\mathrm{R} \\
\text { Square }\end{array}$ & $\begin{array}{c}\text { Adjusted R } \\
\text { Square }\end{array}$ & $\begin{array}{c}\text { of the } \\
\text { Estimate }\end{array}$ & $\begin{array}{l}\text { R Square } \\
\text { Change }\end{array}$ & $\begin{array}{c}\mathrm{F} \\
\text { Change } \\
\end{array}$ & $\mathrm{df1}$ & $\mathrm{df2}$ & $\begin{array}{l}\text { Sig. F } \\
\text { Change }\end{array}$ \\
\hline 1 & $.712^{\mathrm{a}}$ & .507 & .492 & 7.04915 & .507 & 33.885 & 1 & 33 & .000 \\
\hline
\end{tabular}

a. Predictors: (Constant), Jejaring Sosial FB

b. Dependent Variable: Prestasi IMK

TABEL V

UJI KOEFESIEN REGRESI VARIABEL JEJARING SOSIAL FACEBOOK (X) TERHADAPVARIABEL PRESTASI BELAJAR IMK (Y)

\begin{tabular}{|c|c|c|c|c|c|c|}
\hline \multicolumn{7}{|c|}{$\mathrm{ANOVA}^{b}$} \\
\hline Mod & & Sum of Squares & $d f$ & Mean Square & $\mathrm{F}$ & Sig. \\
\hline \multirow[t]{3}{*}{1} & Regression & 1683.757 & 1 & 1683.757 & 33.885 & $.000^{3}$ \\
\hline & Residual & 1639.786 & 33 & 49.690 & & \\
\hline & Total & 3323.543 & 34 & & & \\
\hline
\end{tabular}

a. Predictors: (Constant), Jejaring Sosial FB

b. Dependent Variable: Prestasi IMK
TABEL VI

UJI KOEFESIEN REGRESI DAN SIGNIFIKANSINYA

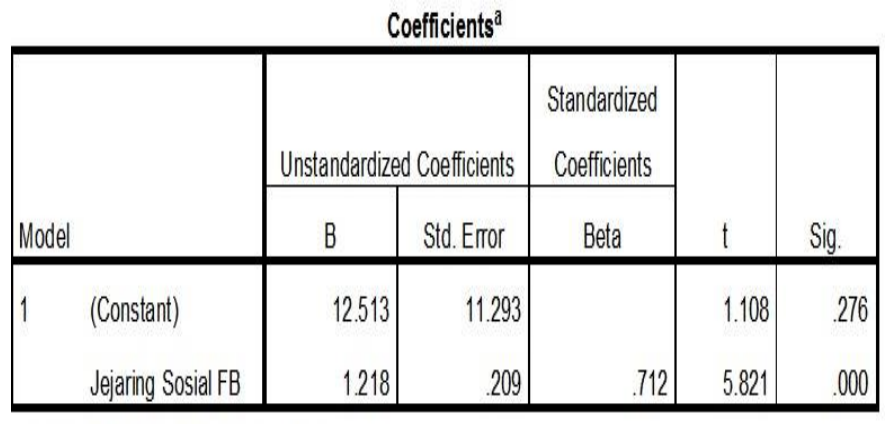

a. Dependent Vaniable: Prestasi IIMK

Pengaruh Variabel Jejaring Social Facebook (X) terhadap Variabel Prestasi Belajar IMK Mahasiswa (Y).
$\mathrm{H}_{0}: \beta=0$,
$\mathrm{H}_{0}: ß \neq 0$
Artinya:

$\mathrm{H}_{0} \quad$ : Tidak terdapat pengaruh jejaring sosial facebook terhadap prestasi belajar IMK mahasiswa.

$\mathrm{H}_{1}$ : Terdapat pengaruh jejaring sosial facebook terhadap prestasi belajar IMK Mahasiswa.

Berdasarkan Tabel IV di atas, terlihat bahwa koefisien korelasi pengaruh variabel bebas jejaring sosial facebook (X) terhadap prestasi belajar IMK mahasiswa (Y) adalah sebesar 0.712 .

Sedangkan koefisien determinasinya ( $R$ square) sebesar 0.507 menunjukan bahwa besarnya kontribusi jejaring sosial facebook terhadap prestasi belajar IMK mahasiswa adalah sebesar 50,70\% (mayoritas), sisanya (sebesar 40,30\%) disebabkan faktor lainnya..

Untuk pengujian hipotesis melalui analisis regresi diperoleh hasil perhitungan seperti yang terlihat pada Tabel V dan Tabel VI Berdasarkan Tabel VI diperoleh persamaan garis regresi yang mempresentasikan pengaruh variabel jejaring sosial facebook $(\mathrm{X})$ dan terhadap variabel prestasi belajar IMK (Y), yaitu: $\overline{\mathbf{Y}}=\mathbf{1 2 , 5 1 3}+\mathbf{1 , 2 1 8 X}$.

Sementara untuk mengujisignifikansi garis regresi tersebut adalah dengan memperhatikan hasil perhitungan yang ada pada Tabel V Menurut ketentuan yang ada, kriteriasignifikansi regresi tersebut adalah "jika nilai $\mathbf{S i g}<0,05$ maka $\mathrm{H}_{0}$ ditolak dan $\mathrm{H}_{1}$ diterima" atau "jika $\mathbf{F}_{\text {hitung }}>\mathbf{F}_{\text {tabel }}$ maka $\mathrm{H}_{0}$ juga ditolak atau $\mathrm{H}_{1}$ diterima", yang berarti bahwa koefisien regresi tersebut signifikan. Dengan kata lain kita dapat simpulkan bahwa terdapat pengaruh yang signifikan variabel bebas jejaring sosial facebook $(\mathrm{X})$ terhadap variabel terikat prestasi belajar IMK mahasiswa (Y). Nilai signifikansi (Sig) adalah bilangan yang tertera pada kolom Sig. dalam Tabel V Nilai

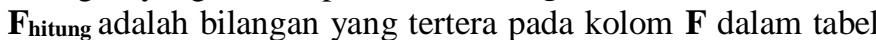
yang sama. Nilai $\mathbf{F}_{\text {tabel }}$ adalah nilai tabel distribusi-F untuk taraf nyata $5 \%$ dengan derajat pembilang $(\mathrm{k})=1$ dan derajat penyebut $(\mathrm{n}-\mathrm{k}-1)=33$, dimana $\mathrm{n}$ banyaknya responden dan $\mathrm{k}$ banyaknya variabel bebas, maka nilai $\mathbf{F}_{\text {tabel }} 4,15$. 
Berdasarkan Tabel VI terlihat bahwa nilai Fitung $_{\mathbf{3 3 , 8 5}}$ lebih besar dari 4,15 dan Sig. 0.000 lebih kecil dari 0.05 maka $\mathrm{H}_{0}$ ditolak dan $\mathrm{H}_{1}$ otomatis diterima yang berarti bahwa koefisien regresi tersebut signifikan. Jadi dapat dikatakan bahwa terdapat pengaruh yang signifikan antara variabel bebas jejaring sosial facebook (X) terhadap prestasi belajar IMK mahasiswa (Y).

Berdasarkan hasil pengujian korelasi maupun regresi tersebut maka disimpulkan bahwa terdapat pengaruh variabel bebas jejaring sosial facebook (X) terhadap prestasi belajar IMK mahasiswa (Y)

\section{KESIMPULAN DAN SARAN}

Berdasarkan hasil pengumpulan data, pemrosesan dan pengujian hipotesis, maka dapat disimpulkan:

1. Terdapat korelasi antara jejaring social facebook dengan prestasi belajar mahasiswa, bahwa koefisien korelasi pengaruh variabel bebas jejaring sosial facebook (X) terhadap prestasi belajar IMK mahasiswa (Y) adalah sebesar 0.712. Sedangkan koefisien determinasinya $(R$ square) sebesar 0.507 menunjukan bahwa besarnya kontribusi jejaring sosial facebook terhadap prestasi belajar IMK mahasiswa adalah sebesar 50,70\% (mayoritas), sisanya (sebesar 40,30\%) disebabkan faktor lainnya.

2. Terdapat pengaruh yang signifikan antara variabel bebas jejaring sosial facebook (X) terhadap prestasi belajar IMK mahasiswa (Y). Hal ini terlihat dari hasil uji regresi linier sederhana yang ditunjukkan dengan nilai sig.0,00 < 0,05. Bahwa nilai $\mathbf{F}_{\text {hitung }} \mathbf{3 3 , 8 5}$ lebih besar dari 4,15 dan Sig. 0.000 lebih kecil dari 0.05 maka $\mathrm{H}_{0}$ ditolak dan $\mathrm{H}_{1}$ otomatis diterima yang berarti bahwa koefisien regresi tersebut signifikan.

Berdasarkan hasil pengolahan data dan simpulan yang kami paparkan adapun saran yang hendak disampaikan yaitu penelitian ini hanya memuat satu variabel bebas. Sehingga untuk hasil yang lebih optimal sebaiknya memasukkan kemungkinan variable lain yang dapat mempengaruhi prestasi belajar mahasiswa.

\section{REFERENSI}

[1] Tulus, Tu'u. Peran Disiplin pada Perilaku dan Prestasi Siswa. Jakarta: Rineka Cipta. 2004.

[2] Slameto. Belajar dan Faktor-Faktor yang Mempengaruhinya. Jakarta: Rineka Cipta. 2003.

[3] Alghamdi, M.A. 2012. The Influence of Facebook Friends on Consumers' Purchase Decisions. University of Otago, Dunedin, New Zealand

[4] Permana, Wim, Pemanfaatan e-learning sebagai Pendukung Kegiatan Belajar Mengajar Universitas Terbuka di Indonesia: Studi Perangkat Lunak, Program Studi Ilmu Komputer, FMIPA, UGM, Yogyakarta. [online, tersedia di:http://wimkhan.wordpress.com,diakses April 2015].

[5] Hambali, Dwi Asharialdy, Aplikasi Penyebaran Tugas Kerja Berbasis Jejaring Sosial Facebook, Program Studi Ilmu Komputer FMIPA Universitas Pendidikan Indonesia, Jakarta. 2008.

[6] Poerwanto, Ngalim. Psikologi Pendidikan. Bandung: PT Rosda Karya 2007

[7] Djamarah, Syaiful Bahri. Prestasi Belajar dan kompetensi Guru. Surabaya: UsahaNasional. 1994.
[8] Ni'am, Moh. Khoirun, Rudy Kustijono. Pengembangan Pembelajaran SMP Melalui Facebook pada Materi Alat Optik., Jurnal Inovasi Pendidikan Fisika Vol. 02 No. 03 Hal: 208-211. 2013.

[9] Nuryani, Evi. Hubungan Intensitas Mengakses Facebook dengan Motivasi Belajar Siswa SMA Negeri 2 Tenggarong Seberang, eJournal Ilmu Komunikasi, 2(3) : 178-192. 2014.

[10] Setyono, Evin Yudhi, Pengaruh Penggunaan Media Jejaring Sosial Edmodo Terhadap Hasil Belajar Mahasiswa Pada Topik Pembuatan Kurva-S Menggunakan Microsoft Excell. Jurnal Sosial dan Humaniora, Vol.5, No. 1, hlm. 42-49. 2015. 